\title{
High-resolution facies zonation within a cold-water coral mound: The case of the Piddington Mound, Porcupine Seabight, NE Atlantic
}

\author{
Lim Aaron ${ }^{1,{ }^{*}}$, Wheeler Andrew J. ${ }^{1,2}$, Arnaubec Aurelien ${ }^{3}$
}

\author{
${ }^{1}$ School of Biological, Earth and Environmental Sciences, University College Cork, Distillery Fields, \\ North Mall, Cork, Ireland \\ ${ }^{2}$ Irish Centre for Research in Applied Geosciences, University College Cork, Ireland \\ ${ }^{3}$ Unité Systèmes sous-Marins, Centre de Méditerranée, Ifremer, Zone Portuaire de Brégaillon, CS \\ 20330, 83507 La Seyne/Mer Cedex, France
}

* Corresponding author : Aaron Lim, email address : aaron.lim@ucc.ie

\begin{abstract}
:
Framework-forming cold-water corals (CWC's) such as Lophelia pertusa and Madrepora oculata generate positive topographic features on the seabed called CWC mounds. In the North East Atlantic, CWC mounds have been studied in detail and reveal heterogeneous spatial on-mound organisation of coral patches. Many of these studies are limited by a paucity of remotely-sensed and video imagery at an appropriate resolution and coverage. This study is the first attempt to video mosaic an entire CWC mound (the Piddington Mound of the Moira Mounds, Porcupine Seabight, Irish margin). The mosaic is divided into 18,980 $0.25 \mathrm{~m} 2$ cells with a manual classification applied to each within a geographic information system (GIS). Geospatial analysis shows that cell distribution is not random but clustered significantly across the mound surface. These clusters of cells make up a ring-like facies pattern. A model for the processes that lead to this facies pattern is suggested based on contemporary environmental controls. Parallels to shallow-water reef atolls are also drawn which subsequently has implications for interpreting fossil coral outcrops.
\end{abstract}

\section{Highlights}

We present the first attempt at video mosaicking an entire CWC mound. Detailed facies distribution analyses are utilised to demonstrate facies organisation across the Piddington Mound surface. Main facies on the Piddington Mound are Live coral framework, Dead coral framework and Coral rubble. Coral rubble dominates the summit while live coral framework facies dominate the upper mound flanks. We interpret potential influences on this distribution and draw some parallels with shallow water reef atolls.

Keywords : Cold-water coral, Habitat mapping, Spatial analysis, Sediments, Facies distribution 


\section{Introduction}

Framework-forming, scleractinian cold-water corals (CWCs) are sessile, filter-feeding organisms that can baffle current-suspended sediment and biogenic material between their framework (Roberts et al., 2006). Lophelia pertusa, the most common framework-forming CWC in the NE Atlantic, has been found as shallow as $39 \mathrm{~m}$ water depth and as deep as 4000 m water depth (Freiwald et al., 2004; Roberts et al., 2006). In general, it occurs in temperatures between 4 and $13^{\circ} \mathrm{C}$ (Freiwald, 2002) and has proven to be tolerant of a wide range of salinities, from 31.7 - $38.8 \%$ (Davies et al., 2008). As the coral framework grows, it baffles sediment which can help to generate topographic features on the seabed called CWC reefs and, through successive periods of reef development, CWC carbonate mounds (Freiwald, 2002; Roberts et al., 2009). Here, we refer to mound-shaped, positive topographic features developed by CWC's as CWC mounds. CWC mounds are common in the NE Atlantic (Wheeler et al., 2007), specifically where internal waves concentrate food particles (phytodetritus) which is delivered

to CWCs by enhanced bottom currents (Dullo et al., 2008; Mienis et al., 2009; White and Dorschel, 2010). 
Habitat mapping has proved to be a valuable, efficient and cost-effective tool in understanding the marine environment (e.g. Huang et al., 2011; Lamarche et al., 2011) including CWC habitats (Savini et al., 2014). Multibeam Echosounder (MBES) bathymetry and backscatter have been used extensively to characterise current dynamics and their influence on CWC mound morphology and development e.g. in the Straits of Florida, W Atlantic (Correa et al., 2012a; Correa et al., 2012b) and the midslope Moira Mounds, Porcupine Seabight, NE Atlantic (Foubert et al., 2011). Recently, more advanced approaches to MBES surveying have imaged CWC habitats in deep water using ROV-borne MBES (Dolan et al., 2008; Foubert et al., 2011), on submarine terraces using AUV-borne MBES (Correa et al., 2012a) and on vertical cliff faces in submarine canyons using forward-facing ROV-borne MBES (Huvenne et al., 2011).

In the absence of adequate multibeam data, other studies (e.g. Dorschel et al., 2007; Wheeler et al., 2008) avail of current data, sediment types, video data and/or side scan sonar (SSS) surveying integrated within a Geographical Information System (GIS) to highlight the role of currents and sediment supply on CWC mounds. Seabed sediment samples are an effective way of studying CWC mounds although limited by the spatial representation of the sample (e.g. Day grab, $<0.5 \mathrm{~m}^{2}$ ). Video surveys can discriminate the seabed across substantial areas and are widely used in CWC habitat inspections (Foubert et al., 2005; Huvenne et al., 2005; Vertino et al., 2010). Recent advances in underwater imaging have made high-resolution underwater imagery with accurate positioning in deep water environments possible (Kocak and Caimi, 2005). As a result, since 2005, the utilisation of ROV-based observations for facies information from CWC mounds has increased dramatically (e.g. De Mol et al., 2007; Foubert et al., 2008; Guinan et al., 2009; Hebbeln et al., 2014; Heindel et al., 2010; Huvenne et al., 2016; Purser, 2015; Wienberg et al., 2013). Huvenne et al. (2005) demonstrate the variability between entire mound provinces along the Irish Margin highlighting both the frequency and variability of CWC mounds within the Belgica Mound Province. Later, Dorschel et al. (2007) observed a 
correlation between living coral and enhanced bottom currents in the Belgica Mound Province and outlined the influence of contour currents, tidal currents and local topography on the distinct coral facies distribution across the Galway Mound. Results from other ROV-based facies mapping also highlight the strong relationship between local currents and facies distribution across a mound surface. For example, the Franken Mound, a CWC mound in a state of "mound retirement" at the western Rockall Bank, shows a distinct facies distribution across the mound with living coral dominating the summit region (Wienberg et al., 2008). Many other uses for ROV-based facies observations were realised. Heindel et al. (2010) test, for the first time, a method of spatial prediction mapping (maximum likelihood classification) on a CWC ecosystem providing detailed aerial estimates of CWC-typical facies. ROV-based facies observations were utilised to show that $L$. pertusa is restricted to longer term, stable conditions while Madrepora oculata is more tolerant towards environmental fluctuations (Wienberg et al., 2009). Furthermore, its need as a tool in marine reserve designation and implementation is now recognised (Roberts et al., 2005).

In addition, advances in image processing has led to the application of video mosaicking to marine habitat mapping (Rzhanov et al., 2000). For example, Lirman et al. (2007) accurately characterise a tropical coral reef in shallow water using an entire reef-scale video mosaic. However, no such study has been carried out on an entire CWC mound although small parts of CWC habitats have been manually photo mosaicked (Wheeler et al., 2011).

The need for more local-scale studies and data sets of equal resolution have previously been highlighted (Dolan et al., 2008). This study presents the first attempt of video mosaicking an entire cold-water coral mound and subsequent analyses providing an in-depth facies mapping exercise allowing to discuss facies organisation and potential facies organisational influences. 


\subsection{Study Site}

The Belgica Mound Province (BMP), partly enclosed with a Special Area of Conservation (SAC) designated under the EU Habitats Directive, is located on the eastern flank of the Porcupine Seabight, NE Atlantic (see Fig. 1) (Beyer et al., 2003; Dorschel et al., 2007; Huvenne et al., 2002). It contains an abundance of (giant) CWC mounds, including the wellstudied Galway Mound, Thérèse Mound and Challenger Mound (De Mol et al., 2007; Dorschel et al., 2007; Eisele et al., 2008; Huvenne et al., 2009; Kano et al., 2007; Thierens et al., 2010; Titschack et al., 2009; Wheeler et al., 2005). Two distinct CWC mound chains have been identified, orientated roughly N-S (parallel to depth contours) (Wheeler et al., 2005). Preexisting bathymetry highlights their slight elongate to conical morphology and typical dimensions (approx. $1 \mathrm{~km}$ across and $100 \mathrm{~m}$ tall) (Beyer et al., 2003). To the east, these large CWC mounds are enclosed by the continental shelf and to the west, the Arwen Channel runs through the BMP (Murphy and Wheeler, 2017; Van Rooij, 2004). Towards the south and southwest, the Porcupine Seabight exits out to the abyssal plain (Dorschel et al., 2010) while the north shallows to $500 \mathrm{~m}$, outside the typical depth range for $\mathrm{CWC}$ growth on the Irish continental margin (Dullo et al., 2008; White and Dorschel, 2010)

The Moira Mounds are small-type CWC mounds (approx. $30 \mathrm{~m}$ across and $10 \mathrm{~m}$ tall) found throughout the BMP, occurring between 800 - 1100 m water depth (Wheeler et al., 2005). While no definitive dating has confirmed their age, it is speculated that they are Holocene features based on their size, seismic profiles and the surrounding seabed substrate (Foubert et al., 2011; Huvenne et al., 2005; Kozachenko, 2005). The Moira Mounds in the BMP can be further subdivided into 4 areas or chains of mounds based on the distribution of approx. 256 Moira Mounds; the "up-slope area", the "mid-slope area", the "down-slope area" and the "northern area" (Wheeler et al., 2011) (see Fig. 1). While the number of Moira Mounds in the northern and the up-slope areas are relatively sparse, the main focus of research has been 
carried out on the mid- and down-slope areas. The mid-slope area occurs between the chain of large CWC mound structures. The Moira Mounds here are thought to represent mound formation under "stressed" conditions due to high sediment input (Foubert et al., 2011). The down-slope area is unique as it occurs within the Arwen Channel. Unlike the other areas, the CWC's on the Moira Mounds are predominantly growing, are actively trapping sands (Wheeler et al., 2011) and occur outside the influence of other large mound structures.

\section{$<$ INSERT FIGURE 1>}

\section{Materials and Methods}

\subsection{ROV-borne Multibeam Echosounder (MBES)}

ROV-borne MBES data was collected over the Piddington Mound and the surrounding seabed during the QuERCi survey (2015) on board RV Celtic Explorer with the Holland 1 ROV (cruise number CE15009: Wheeler et al. (2015). A high-resolution Kongsberg EM2040 MBES was integrated with a sound velocity probe and mounted on the front-bottom of the ROV. Data were acquired at a frequency of $400 \mathrm{kHz}$ while the ROV maintained a height of $30 \mathrm{~m}$ above the seabed with a survey speed of approximately 2 knots. This achieved a swath width of $\sim 160$ m. Positioning and attitude were obtained using a Kongsberg HAINS inertial navigation system, ultra-short baseline (USBL) system (Sonardyne Ranger 2) and doppler velocity log (DVL). Data acquisition was carried out using SIS software, where calibration values, sensor offsets, navigation and attitude values were incorporated. Two adjacent $170 \mathrm{~m}$ long MBES lines were collected over Piddington Mound and the surrounding seabed. MBES data were stored as *.all and *.wcd files and were processed using CARIS HIPS and SIPS v9.0.14 to apply tidal corrections and clean anomalous data spikes. The cleaned data were saved as a single *.xyz and gridded to a $10 \mathrm{~cm}$ ArcView GRID. 
The $10 \mathrm{~cm}$ MBES grid was imported into ArcMap 10.2 and projected in UTM Zone 29N. A 1 m contour *.shp file was generated using the Arc Toolbox Spatial Analyst Contour tool. Slope (degrees) and aspect were derived from the bathymetry using the Arc Toolbox Spatial Analyst tools.

\subsection{ROV-video data collection}

ROV-video data was collected over Piddington Mound during the VENTuRE survey (2011) on board RV Celtic Explorer with the Holland 1 ROV (cruise number CE11009: Wheeler and shipboard party, 2011). A downward-facing, high-definition camera was mounted on the bottom of the ROV. Positioning and navigation were achieved using a USBL (Sonardyne Ranger 2) and RDI Workhouse DVL. The ROV altimeter recorded and logged the height of the ROV from the seabed. The ROV recorded downward-facing HD video during a series of transects across the mound $<2 \mathrm{~m}$ off the seabed/mound surface.

\subsection{Georeferenced video mosaic generation}

A georeferenced video mosaic has been generated using the IFREMER in-house Matisse software where the raw video data was imported and from which images have been extracted at a rate of 1 per second. Poor quality imagery, possibly due to an excessive fly height, and/or with a poor navigational lock were not included. The associated USBL navigation has been filtered with a sliding median filtering and $2^{\text {nd }}$ order polynomial model fit in order to lower trajectory noise. Image and navigation data have been synchronized so that each image has an initial approximate position. This position is refined later by the mosaicking process. For this refinement, the first process consists of feature detection and matching between images using the SIFT (Scale Invariant Feature Transform) algorithm (Lowe, 1999), known for its strong 
robustness and accuracy. Image matching alone would lead to a drifting mosaic and invalid scale, while USBL navigation alone is not accurate enough for high-quality local-overlapping but gives accurate global positioning. To benefit from the both image matching and USBLnavigation, we merged image and navigation information through a cost function minimization. This developed method is similar to Ferrer et al. (2007) except cost function weights are affected according to image and navigation data standard deviations so reprojection errors are minimized in the mosaicking plane rather than the image plane.

After this step, image positions are refined and the mosaic can be drawn. This is carried out with state of the art seaming and blending techniques after Burt and Adelson (1983) and Kwatra et al. (2003).

\subsection{Seabed classification}

As the ROV could not be maintained at a constant height above the seabed in video surveying mode in strong currents, seawater-induced blue-shift varied across the video mosaic. Hence, neither a supervised nor an unsupervised (automatic) seabed classification could be utilized. Instead, a manual classification was applied to each cell of the entire video mosaic. An ArcMap fishnet with a cell size of $0.25 \mathrm{~m}^{2}$ was overlaid on the video mosaic to manage the supervised classification at the highest resolution possible where each $0.25 \mathrm{~m}^{2}$ cell can be inspected and classified (totally 18,980 cells).

Classifiers were based on preliminary assessment of the video mosaic and other CWC habitat ROV-dive-based facies classification from previous work, some of which have similar objectives or are proximal to the study site (e.g. Dorschel et al., 2007; Dorschel et al., 2009; Douarin et al., 2014; Heindel et al., 2010; Huvenne et al., 2005; Spezzaferri et al., 2012; Vertino et al., 2010; Vertino et al., 2015; Wheeler et al., 2005; Wienberg et al., 2008; Wienberg et al., 2009). The facies classifiers are: "hemipelagic sediment with dropstones", "coral 
rubble", "hemipelagic sediment", "dead coral framework" and "live coral framework" (see Fig. 2 for examples and results for detailed facies descriptions).

As each individual cell is inspected and a suitable class chosen, a value was assigned to an attribute table. Several preliminary classifications were applied to the video mosaic in different locations to test the individual classifiers and the classification itself. Some areas of the preliminary classification were re-classified and compared to their initial classification to ensure classification accuracy. The entire video mosaic was then classified and saved as a *.shp file.

\subsection{Video-mosaic analysis}

Spatial dependency is measured by various spatial autocorrelation statistics (e.g. Moran's $I$ : Goodchild, 1986). However, these are unrepresentative when spatial autocorrelation varies significantly over the study site. More suitably, Anselin (1995) developed local indicators for spatial association (LISA) which, in contrast to other methods, measures local variation within patterns of spatial dependence that may not be represented in existing techniques. A widelyused LISA is the $G$ statistic (Getis and Ord, 1992; Ord and Getis, 1995). This measures how concentrated high or low values are for a given study area by calculating a z-score (standard score) and p-value (calculated probability) of a set of geographical values. Here, it is utilised to measure the degree of clustering of the classified cells via the Arc Toolbox spatial statistics tools (High/Low clustering Tool) based on Euclidean distances.

The classified *.shp file was converted to a raster using the conversion tools in Arc Toolbox and imported to the Focal Statistics tool. This calculates, for each input cell location, a statistic of the value that occurs most often (majority) within a specified neighbourhood around it. The 
specified neighbour was calculated based on a potential navigational error of the ROV $(<5 \mathrm{~m})$. Therefore, the neighbourhood was defined as $2.5 \mathrm{~m}$ radius around each cell location.

\section{Results}

\subsection{Video mosaic}

The video mosaic was generated from approximately 8 hours of high-definition video data. The data was collected by means of a series of over lapping lines covering the mound and immediate off-mound area. The video mosaic is shown in Fig. 2, holes in the mosaic are a result of data rejection. For subsequent display purposes, colours on the mosaic were adjusted manually selecting both a white and black reference within Corel Draw software package.

\section{<INSERT FIGURE 2>}

\subsection{Bathymetry and slope}

Piddington Mound exists in an area with several other mounds (Fig. 3A). It has a similar size (11.8 $\mathrm{m}$ tall, $60 \mathrm{~m} \times 40 \mathrm{~m}$ across) and morphology (slightly elongated conical) as the surrounding mounds and it has substantial scouring (1 m - $3 \mathrm{~m}$ deep) at its southern limit. Sinuous megaripples (sediment waves) exist across the area around these mounds. They have a wavelength of $\sim 10 \mathrm{~m}$ and a wave height of $20 \mathrm{~cm}-75 \mathrm{~cm}$. To the south of each mound, there are positive, ridge-shaped features $0.5 \mathrm{~m}-2 \mathrm{~m}$ tall. These features are unlike the sediment waves as they are larger than the sediment waves, have coral colonising them and biogenic material deposited in their troughs as shown by the oblique video footage (Fig. 4). These ridge and wave features are not included in the facies classification as they are not on the Piddington Mound or in the immediate environment and therefore not covered by the video mosaic.

<INSERT FIGURE 3> 


\section{<INSERT FIGURE 4>}

Bathymetry-derived slope is presented in figure 3B. Here, flat seabed slopes (minimum slope of $0^{\circ}$ ) are represented by a deep blue colour while the steep seabed slopes (maximum slope of $55.7^{\circ}$ ) are represented by the red colour. Note that regional slope angle in this area is $1.2^{\circ}$. The steepest areas are found on the flanks of the mounds with slopes dipping as steep as $55^{\circ}$. The summit of each mound is relatively flat $\left(0-6^{\circ}\right)$ as are areas away from the mounds $\left(0^{\circ}-6^{\circ}\right)$ (Fig. 3B). This figure also includes the slip faces of mega ripples in the areas away from the mounds. These appear sinuous to cuspate with a wavelength of $7 \mathrm{~m}-10 \mathrm{~m}$ and wave height of $4 \mathrm{~cm}-20 \mathrm{~cm}$ with an east-west crest alignment. The larger coral colonised ridge-shaped features $(0.5 \mathrm{~m}-2 \mathrm{~m}$ tall) south of the mounds are morphologically distinct, with short eastwest aligned linear crests and a wavelength of approx. $10 \mathrm{~m}$. They diminish in size away from the mounds.

\subsection{Seabed classification}

\section{<INSERT FIGURE 5>}

The "hemipelagic sediment with dropstones" class is characterised by the cell being dominated (>50\% cell coverage) by dropstones and sediment (sand or mud). This class occurs most commonly around the mound perimeter. The "coral rubble" class is characterised by a cell dominated ( $>50 \%$ cell coverage) by recognisable biogenic material (i.e. coral rubble, shell fragments) and sediment. This class most commonly occurs in a $10 \mathrm{~m}$ wide ring immediately enclosed by the "hemipelagic sediment with dropstones" class. However, minor occurrences of this class exist both to the centre of the mound and outside of this ring. This ring is elongate in the same direction of the current $(\mathrm{N}-\mathrm{S})$. The "hemipelagic sediment with dropstones" and "coral rubble" classes are the most frequent classified cells in the video mosaic (Fig.5). The 
"hemipelagic sediment" class is characterised by the cell being dominated $(>90 \%$ cell coverage) by hemipelagic sediment i.e. sand or mud with no recognisable bioclasts or dropstones. It is the least common class and occurs in small clusters less than $0.75 \mathrm{~m}$ wide typically around the edges of the "coral rubble" class. The "dead coral framework" class is characterised by the cell being dominated ( $>50 \%$ cell coverage) coral framework which has no identifiable living parts. This class occurs across the mound but is concentrated in the centre and southern central area as a North-South-elongate ring. The "live coral framework" class is characterised by the cell being dominated ( $>50 \%$ cell coverage) by coral framework with identifiable living parts (polyps or mucus-covered frameworks evident) although major proportions of the coral framework may be dead. It is found across the mound, but is concentrated in the northern central area.

\subsection{Spatial statistical analysis}

The High-Low Clustering (Getis-Ord General G) analysis indicates the concentration of clustering. It firstly applies a null hypothesis to determine if clustering occurs. In this case, with a large Z-score $(168.89)$ and small p-value $(<0.001)$, the null hypothesis can be rejected meaning that clustering occurs. A positive Z-score indicates that high-values (coral frameworks) cluster.

The majority value of cells in the specified neighbourhood (2.5 m radius) (Fig. 6) reveals 4 facies occurring in 5 areas: "Hemipelagic sediment and dropstone" facies, "Coral rubble" facies, "Dead coral framework" facies, and "Live coral framework" facies. This means that in these facies, a particular cell-type dominates, as shown by the focal statistic (majority) based on a $2.5 \mathrm{~m}$ radius. The distribution of these facies closely follows the distribution of observed common occurrence of the individual classified cells. These facies have a ring/annulus-like distribution. 
The "Hemipelagic sediment and dropstone" facies exists in the outer rim of this ring/annulus shape. It is made up of $74.9 \%$ "hemipelagic sediment and dropstone" cells, $15.9 \%$ "coral rubble" cells, $2.3 \%$ "dead coral framework" cells, $1.6 \%$ "hemipelagic sediment" cells and $1.3 \%$ "live coral framework" cells (Fig. 6b).

Immediately inside the "Hemipelagic sediment with dropstone" facies, the "Coral rubble" facies exists. However, this facies also protrudes $11.5 \mathrm{~m}$ through this facies NW of the mound and exists on the highest point of the mound (at $-968 \mathrm{~m}$ water depth) protruding $11.5 \mathrm{~m}$ towards the ENE. It is made up of $60.6 \%$ "coral rubble" cells, $16.5 \%$ "dead coral framework" cells, 6.9\% "live coral framework" cells, 6.3\% "hemipelagic sediment and dropstone" cells and 1.6\% "hemipelagic sediment" cells (Fig. 6b).

The "Dead coral framework" facies exists immediately inside the main body of the "Coral rubble" facies ring. It has a U-shape where the centre of the " $U$ " is broadly based around the highest point on the mound. This facies is made up of $53.1 \%$ "dead coral framework" cells, $24.3 \%$ "coral rubble" cells, $17.4 \%$ "live coral framework" cells, $0.6 \%$ "hemipelagic sediment" cells and $0.1 \%$ "hemipelagic sediment and dropstone" cells (Fig. 6b).

Finally, the "Live coral framework" facies occurs $4.8 \mathrm{~m}$ north of the highest point on the mound, where it completes the U-shape of the "Dead coral framework zone" to make a complete ring, encircling the central "Coral rubble" facies. This zone has an irregular morphology where the zone is intruded by minor occurrences of the "Dead coral framework" facies. It is made up of $47.8 \%$ "live coral framework" cells, $32.1 \%$ "dead coral framework" cells, $13.6 \%$ "coral rubble" cells, $0.2 \%$ "hemipelagic sediment" cells and $0 \%$ "hemipelagic sediment and dropstone" cells (Fig. 6b). 
The "hemipelagic sediment" cells were not common enough in any neighbourhood $(2.5 \mathrm{~m})$ to develop its own facies in the focal statistics tool. However, their distribution in relation to these facies is noted.

\section{$<$ INSERT FIGURE 6>}

\section{Discussion}

\subsection{Local sedimentary environment}

East-west orientated sediment waves surrounding Piddington Mound and its neighbouring mounds suggest a high-energy, bottom current-influenced, sedimentary environment (Foubert et al., 2011). The cross-profile morphology (steepened lee slope) of the sediment waves suggest a south to north prevailing current across the area (Fig. 3B). The current-orientated, elongate morphology may be owed to the dominance of currents here. In fact, substantial scouring around the base of the mounds (Fig. 3A) highlights the intensity of these currents. The larger ridge-form features (see Fig. 3A) to the south of the mounds may no longer be active sediment transport bedforms as the presence of coral on them suggest stability since the growth of the corals seen on the surface (see Fig. 4). However, as the internal composition is unknown nothing about their origin can be said with certainty. De Mol et al. (2007) and Wheeler et al. (2007) describe similar coral-topped features at the base of the Thérèse Mound.

\subsection{Piddington Mound spatial organisation}

The off-mound area of the Moira Mounds has been previously described (see Foubert et al., 2011; Wheeler et al., 2005). Off-mound areas are typically less spatially heterogeneous than the on-mound areas (e.g. Vertino et al., 2010). The video mosaic covers the entire Piddington Mound surface and the immediate off-mound area, allowing inclusion of the full-mound surface in the analyses. Further, the chosen resolution of the analyses is both commensurate 
with typical box core footprints used to study other CWC mounds and is of sufficient resolution to map facies change and distribution.

The G-statistic reveals that, despite the heterogeneous nature of the facies on Piddington Mound observed from the video mosaic at a $0.25 \mathrm{~m}^{2}$ scale, there is a statistically significant clustered pattern. The focal statistics layer shows the geographic distribution of cell-type dominance (Fig. 6a). The ring-like pattern of these dominating cell-types is clearly focussed around the summit of Piddington Mound observed in the bathymetric data (Fig. 3A). This ringlike clustered pattern is made up of facies typical of CWC mounds ("Live coral framework", "Dead coral framework" and "Coral rubble"). Similar facies have been identified at the nearby Galway Mound (Dorschel et al., 2007), other Moira Mounds (Foubert et al., 2011; Wheeler et al., 2005), Atlantis Mound and Yellow Chain at the Santa Maria di Leuca Coral Province in the Mediterranean (Vertino et al., 2010), Franken Mound (Wienberg et al., 2008), Propeller Mound (Heindel et al., 2010) and various mound provinces within the Porcupine Seabight (Huvenne et al., 2005). The distribution of these mound-typical facies closely follows the mound depth contours. Where the seabed becomes relatively flat, surrounding Piddington Mound (Fig. 3B), it is characterised by "Hemipelagic sediment with dropstones" facies which is the typical background facies present in the area (Foubert et al., 2011). It is therefore likely that the on-mound facies distribution can be attributed to the presence of corals where each facies may represent the result of a dominant process or set of processes at that part of the mound. The "Live coral framework" area slightly to the north of the Piddington Mound summit is the area on the mound where coral growth dominates. The "Coral rubble" areas on the mound, found near the summit and on the fringes of the mound, represent the areas where notable accumulations of eroded (physical or biological) coral and other biogenic material has been deposited. The "Dead coral framework" area found mainly on the flanks of the mound and are typically found where the "Coral rubble" and "Live coral framework" intersect. This 
area represents an area where live coral growth no longer dominates and older framework remains exposed.

\subsection{Influences on facies distribution}

The "Hemipelagic sediment and dropstone" facies dominates around the Piddington Mound within the surrounding scour pits (Fig. 3A). Initial deposition of this dropstone-rich layer and posterior re-exposure by erosion is rather unlikely as coring and drilling attempts in the vicinity of the Belgica Mound Province CWC mounds never observed such a layer (e.g. IODP 307 Expedition scientists, 2005). Alternatively, perhaps the dropstones were scattered in hemipelagic sediment in which winnowing of this sediment up-concentrated the dropstones. This would also explain the preferential occurrence of the hemipelagic sediment with dropstone facies within the scour pit.

The "hemipelagic sediment" cell-type is uncommon, existing in very small patches scattered across Piddington Mound. However, its distribution is noted (Fig. 5) occurring in 2 different settings. The first setting is next to coral framework cell-types ("Dead coral framework" and "Live coral framework") where the coral frameworks may act as a physical barrier to erosion for the already deposited sediment from a former lower hydrodynamic energy regime. The second setting is at the boundary between the "hemipelagic sediment and dropstone" cell-types and "coral rubble" cell-types in the current-facing (southern) side of the mound. This deposition of "hemipelagic sediment" may be explained by a sudden change in seabed rugosity slowing the current between these two cell-types, allowing the deposition of current-suspended sediment.

Wilson (1979) proposes a ring-like CWC growth (Wilson Ring model), particularly focussed around the coppice stage (sensu Squires, 1964). Wilson (1979) describe CWC mound 
development in optimum conditions, with limited sediment supply, where autogenic (biogenic) processes dominate; an isolated colony grows and successive rings of coral debris and colonies develop around this initial point (colony). This forms a circular CWC coppice made up of alternating rings of colonies and debris where, presumably, the centre is older than the edges of the structure. However, at the mound-scale, this process of ring-like development seems rather unlikely.

\section{$<$ INSERT FIGURE 7>}

A more likely explanation for the ring-like distribution of facies across the Piddington Mound is based on benthic environmental conditions. Currents are well-known to influence facies distribution across CWC mounds (Dorschel et al., 2007). In fact, previous research show that even local-scale (bio)zonation may be primarily controlled by current flow (Messing et al., 1990). Here, currents are considered as the dominant (allogenic) control on the distribution of facies across Piddington Mound. CWC's preferentially settle on elevated structures where they have access to faster flowing water and enhanced food supply, undiluted by benthic sediment transport processes (Freiwald, 2002; Roberts et al., 2003; Roberts et al., 2006). F1 and F2 (Figure 7) occur relatively high (several meters above the surrounding seabed) on the Piddington Mound. This is also the steepest part of the mound $\left(45-50^{\circ}\right)$ which may be a result of coral trapping sediment and generating topography (Wheeler et al., 2005; Wheeler et al., 2008). Such steepened slopes may cause biologically and physically eroded bioclasts to roll onto the flatter parts of the mound (predominately the downslope R2). Thus, F1 and F2 are likely the source of the bioclasts that make up the "Coral rubble" facies in R2. The central "Coral rubble" facies at the mound summit (R1) occurs upslope and sheltered by a ring of coral framework and therefore its distribution cannot be explained by the same process. Here, this central area is fully encircled by dense coral framework which locally cuts it off from surrounding currents and subsequent food supply. Despite its elevated occurrence, a reduction 
in food supply and current velocity may result in a less favourable environment at this central area. This may explain the degradation of these corals to become an area of coral rubble. As such, 3 comparisons can be drawn between Piddington Mound and shallow-water reef atolls where a) a ring of coral shelters/cuts off the centre, creating a micro-environment, markedly different from the surrounding environment akin to the central lagoon area of a shallow-water reef atoll, b) the slope of the Piddington Mound is similar to that of shallow-water reef atolls $\left(45^{\circ}\right)$ (e.g. Mururoa Atoll) (Chevalier, 1968) and subsequently c) the reef material is transported down its slope (Woodroffe and Biribo, 2011).

On Piddington Mound, the location and distribution of the "Live coral framework" area is interesting as live coral framework is typically found at or near the summit of mounds (Rüggeberg et al., 2011). However, the main loci for live coral growth on different mounds varies from setting to setting: on the summit (e.g. Galway Mound: Dorschel et al. (2007), the lee side of the mound structure (e.g. Giant Mound and the Hedge Mounds: Dorschel et al., 2009), and to the current-facing side of the mound structure (e.g. CWC reefs at Hola, offshore Norway: (Buhl-Mortenson et al., 2015). In the case of the Piddington Mound, it occurs just north of the summit (Fig. 6) on the lee side of the mound. In areas of excessively high current flow on the Porcupine Bank, CWC have been found flourishing on the lee-side of mounds (Dorschel et al., 2009). However, this is unlike other mounds in the eastern Porcupine Seabight (i.e. Galway Mound: Dorschel et al., 2007), and here the summit of Piddington Mound is dominated by Coral rubble facies. Figure $3 \mathrm{C}$ maps the facies types across the Piddington Mound bathymetric cross-profile. Lim (2017) measure a current speed here of $39-41 \mathrm{~cm} \mathrm{~s}^{-1}$ in this area, the highest noted for the western Moira Mounds chain. It may be that the live corals in F2 thrive in the shelter provided by the mound which acts as a physical barrier slowing the currents. Purser et al. (2010) and Orejas et al. (2016) show that Lophelia capture food more effectively in lower flow velocities. However, whilst these are laboratory-based studies, a 
detailed study from the Mingulay Reef Complex may also explain the distribution of live corals on the Piddington Mound where mound topography-induced turbulence may account for enhanced delivery of food particles suspended in deeper water (see Davies et al., 2009).

The facies zonation observed on the Piddington Mound has various implications for the interpretation of coral deposits in fossil outcrop. Coral diversity, coral morphology, sedimenttype (hydrodynamic energy), presence of algae, abundance of pelagic or planktonic components, microborings, surrounding facies or geochemistry are among the numerous recognition criteria to distinguish between shallow- or deep-water occurring CWC mound deposits (Mullins et al., 1981). With more studies available on modern CWC mounds, Hebbeln and Samankassou (2015) show that misinterpretation of some of these distinguishing criteria are possible and, in fact, for many ancient carbonate mounds, formation in deep water appear just as likely as formation in shallow shelf seas. In line with this argument, various comparisons have been outlined herein between the Piddington Mound and shallow water reef atolls. In addition, facies zonations appear common in both modern, shallow-water coral reef build ups (Janßen et al., 2017) and in outcrops (Gischler, 1995; Reolid et al., 2014). Here, the first deepwater CWC mound video mosaic also exhibits a mound-scale facies zonation. Thus, these similarities must also be taken into consideration when interpreting fossil coral outcrops.

\section{Conclusion}

Although video mosaicking an entire CWC mound at this resolution is time consuming in data acquisition, processing and analysis, our investigation offers new, unique and detailed insights to CWC mound organisation and facies distribution. Despite mound surface heterogeneity, areas of the Piddington Mound surface (as small as $0.25 \mathrm{~m}^{2}$ ) cluster significantly in a ring-like pattern focussed around the mound summit. While ring-like observations have been reported 
at other CWC mounds (e.g. Henriet et al., 1998; Wilson, 1979), the facies pattern here is physically dissimilar. A definitive explanation cannot be put forward for the existence of this ring-like facies pattern however, a scenario is put forward based on the influences of the surrounding environment drawing parallels to shallow-water coral atolls. The existence of a facies zonation implies that deep-water CWC mounds are similar to shallow-water coral buildups and this should be taken into consideration when making interpretations from fossil coral outcrops.

Looking to the future, this data set may be used to either compare supervised and unsupervised classification techniques or to ground-truth high-resolution facies distribution prediction models.

\section{Acknowledgements}

The authors would like to thank Jürgen Titschack and an anonymous reviewer for their time and effort in extremely useful and constructive reviews. Further, the authors would like to thank the crew and officers of ROV Holland 1 and RV Celtic Explorer for assistance in collecting high resolution, accurately positioned data. Ship time on the RV Celtic Explorer was funded by the Marine Institute under the 2011 and 2015 Ship Time Programme of the National Development Plan. Aaron Lim is funded by the Irish Research Council Graduate of Ireland Scholarship IRC (2015 - 2016).

\section{References}

Anselin, L., 1995. Local Indicators of Spatial Association-LISA. Geographical Analysis 27 (2), 93-115, 10.1111/j.1538-4632.1995.tb00338.x. 
Beyer, A., Schenke, H.W., Klenke, M., Niederjasper, F., 2003. High resolution bathymetry of the eastern slope of the Porcupine Seabight. Marine Geology 198 (1-2), 27-54, http://dx.doi.org/10.1016/S0025-3227(03)00093-8.

Buhl-Mortenson, L., Hodnesdal, H., Thorsnes, T., 2015. The Norwegian Sea Floor. MAREANO 2015,

Burt, P.J., Adelson, E.H., 1983. A Multiresolution Spline with Application to Image Mosaics. Acm Transactions on Graphics 2 (4), 217-236, Doi 10.1145/245.247.

Chevalier, J.-P., 1968. Etude géomorphologique et bionomique de l'atoll de Mururoa (Tuamotu),

Correa, T.B.S., Eberli, G.P., Grasmueck, M., Reed, J.K., Correa, A.M.S., 2012a. Genesis and morphology of cold-water coral ridges in a unidirectional current regime. Marine Geology 326, 14-27, 10.1016/j.margeo.2012.06.008.

Correa, T.B.S., Grasmueck, M., Eberli, G.P., Reed, J.K., Verwer, K., Purkis, S.A.M., 2012b. Variability of cold-water coral mounds in a high sediment input and tidal current regime, Straits of Florida. Sedimentology 59 (4), 1278-1304, 10.1111/j.1365-3091.2011.01306.x.

Coughlan, M., Wheeler, A.J., Dorschel, B., Lordan, C., Boer, W., Gaever, P.v., Haas, H.d., Mörz, T., 2015. Record of anthropogenic impact on the Western Irish Sea mud belt. Anthropocene 9, 56-69, http://dx.doi.org/10.1016/j.ancene.2015.06.001.

Davies, A.J., Duineveld, G.C., Lavaleye, M.S., Bergman, M.J., van Haren, H., Roberts, J.M., 2009. Downwelling and deep-water bottom currents as food supply mechanisms to the coldwater coral Lophelia pertusa (Scleractinia) at the Mingulay Reef complex. Limnology and Oceanography 54 (2), 620, DOI 10.4319/lo.2009.54.2.0620.

Davies, A.J., Wisshak, M., Orr, J.C., Murray Roberts, J., 2008. Predicting suitable habitat for the cold-water coral Lophelia pertusa (Scleractinia). Deep Sea Research Part I:

Oceanographic Research Papers 55 (8), 1048-1062, 10.1016/j.dsr.2008.04.010.

De Mol, B., Kozachenko, M., Wheeler, A.J., Alvares, H., Henriet, J.-P., Olu-Le Roy, K., 2007. Thérèse Mound: a case study of coral bank development in the Belgica Mound Province, Porcupine Seabight. International Journal of Earth Sciences 96 (1), 103-120, http://dx.doi.org/10.1007/s00531-005-0496-x.

Dolan, M.F.J., Grehan, A.J., Guinan, J.C., Brown, C., 2008. Modelling the local distribution of cold-water corals in relation to bathymetric variables: Adding spatial context to deep-sea video data. Deep-Sea Research I 55 (11), 1564-1579, http://dx.doi.org/10.1016/j.dsr.2008.06.010.

Dorschel, B., Hebbeln, D., Foubert, A., White, M., Wheeler, A.J., 2007. Hydrodynamics and cold-water coral facies distribution related to recent sedimentary processes at Galway Mound west of Ireland. Marine Geology 244 (1-4), 184-195, http://dx.doi.org/10.1016/j.margeo.2007.06.010.

Dorschel, B., Wheeler, A.J., Huvenne, V.A.I., de Haas, H., 2009. Cold-water coral mounds in an erosive environmental setting: TOBI side-scan sonar data and ROV video footage from 
the northwest Porcupine Bank, NE Atlantic. Marine Geology 264 (3-4), 218-229, 10.1016/j.margeo.2009.06.005.

Dorschel, B., Wheeler, A.J., Monteys, X., Verbruggen, K., 2010. Atlas of the Deep-water Seabed: Ireland. Springer, Dordrecht Heidelberg London New York DOI 10.1007/978-90481-9376-1.

Douarin, M., Sinclair, D.J., Elliot, M., Henry, L.-A., Long, D., Mitchison, F., Roberts, J.M., 2014. Changes in fossil assemblage in sediment cores from Mingulay Reef Complex (NE Atlantic): Implications for coral reef build-up. Deep Sea Research Part II: Topical Studies in Oceanography 99, 286-296, http://dx.doi.org/10.1016/j.dsr2.2013.07.022.

Dullo, C., Flögel, S., Rüggeberg, A., 2008. Cold-water coral growth in relation to the hydrography of the Celtic and Nordic European continental margin. Marine Ecology Progress Series 371, 165-176, 10.3354/meps07623.

Eisele, M., Hebbeln, D., Wienberg, C., 2008. Growth history of a cold-water coral covered carbonate mound - Galway Mound, Porcupine Seabight, NE-Atlantic. Marine Geology 253 (3-4), 160-169, 10.1016/j.margeo.2008.05.006.

Ferrer, J., Elibol, A., Delaunoy, O., Gracias, N., Garcia, R., 2007. Large-area photo-mosaics using global alignment and navigation data. MTS/IEEE OCEANS Conference, Vancouver, Canada, pp. 1-9^, http://dx.doi.org/10.1109/OCEANS.2007.4449367.

Foubert, A.T.G., Beck, T., Wheeler, A.J., Opderbecke, J., Grehan, A., Klages, M., Thiede, J., Henriet, J.-P., Polarstern ARK-XIX/3a shipboard party, 2005. New view of the Belgica Mounds, Porcupine Seabight, NE Atlantic: preliminary results from the Polarstern ARKXIX/3a ROV cruise. In: Freiwald, A., Roberts, J.M. (Eds.), Deep-water corals and Ecosystems, . Springer-Verlag, Berlin Heidelberg, pp. 403-415,

Foubert, A.T.G., Depreiter, D., Beck, T., Maignien, L., Pannemans, B., Frank, N., Blamart, D., Henriet, J.-P., 2008. Carbonate mounds in a mud volcano province off north-west Morocco: Key to processes and controls. Marine Geology 248, 74-96,

Foubert, A.T.G., Huvenne, V.A.I., Wheeler, A.J., Kozachenko, M., Opderbecke, J., Henriet, J.-P., 2011. The Moira Mounds, small cold-water coral mounds in the Porcupine Seabight, NE Atlantic: Part B - Evaluating the impact of sediment dynamics through high-resolution ROV-borne bathymetric mapping Marine Geology 282 (1-2), 65-78, doi:10.1016/j.margeo.2011.02.008

Freiwald, A., 2002. Reef-Forming Cold-Water Corals. In: Wefer, G., Billett, D.S.M., Hebbeln, D., Jørgensen, B.B., van Weering, T.C.E. (Eds.), Ocean Margin Systems. Springer, Berlin Heidelberg New York, pp. 365-385, http://dx.doi.org/10.1007/978-3-662-05127-6_23.

Freiwald, A., Fosså, J.H., Grehan, A., Koslow, T., Roberts, J.M., 2004. Cold-water coral reefs. UNEP-WCMC, Cambridge, UK 84,

Getis, A., Ord, J.K., 1992. The Analysis of Spatial Association by Use of Distance Statistics. Geographical Analysis 24 (3), 189-206, 10.1111/j.1538-4632.1992.tb00261.x.

Gischler, E., 1995. Current and Wind Induced Facies Patterns in a Devonian Atoll: Iberg Reef, Harz Mts., Germany. Palaios 10 (2), 180-189, 10.2307/3515181. 
Goodchild, M., 1986. Spatial Autocorrelation. Concepts and Techniques in Modern Geography 47. Norwich, UK: Geo Books, https://alexsingleton.files.wordpress.com/2014/09/47-spatial-aurocorrelation.pdf

Guinan, J., Grehan, A.J., Dolan, M.F.J., Brown, C., 2009. Quantifying relationships between video observations of cold-water coral cover and seafloor features in Rockall Trough, west of Ireland. Marine Ecology Progress Series 375, 125-138, 10.3354/meps07739.

Hebbeln, D., Samankassou, E., 2015. Where did ancient carbonate mounds grow - In bathyal depths or in shallow shelf waters? Earth-Science Reviews 145, 56-65, http://dx.doi.org/10.1016/j.earscirev.2015.03.001.

Hebbeln, D., Wienberg, C., Wintersteller, P., Freiwald, A., Becker, M., Beuck, L., Dullo, C., Eberli, G.P., Glogowski, S., Matos, L., 2014. Environmental forcing of the Campeche coldwater coral province, southern Gulf of Mexico.

Heindel, K., Titschack, J., Dorschel, B., Huvenne, V.A.I., Freiwald, A., 2010. The sediment composition and predictive mapping of facies on the Propeller Mound-A cold-water coral mound (Porcupine Seabight, NE Atlantic). Continental Shelf Research 30 (17), 1814-1829, doi:10.1016/j.csr.2010.08.007.

Henriet, J.-P., De Mol, B., Pillen, S., Vanneste, M., Van Rooij, D., Versteeg, W., Croker, P.F., Shannon, P.M., Unnithan, V., Bouriak, S., Chachkine, P., BELGICA 97 Shipboard scientific crew, 1998. Gas hydrate crystals may help build reefs. Nature 391 (6668), 648-649, Doi $10.1038 / 35530$.

Huang, Z., Brooke, B.P., Harris, P.T., 2011. A new approach to mapping marine benthic habitats using physical environmental data. Continental Shelf Research 31 (2, Supplement), S4-S16, http://dx.doi.org/10.1016/j.csr.2010.03.012.

Huvenne, V.A., Tyler, P.A., Masson, D.G., Fisher, E.H., Hauton, C., Huhnerbach, V., Le Bas, T.P., Wolff, G.A., 2011. A picture on the wall: innovative mapping reveals cold-water coral refuge in submarine canyon. PLoS ONE 6 (12), e28755, 10.1371/journal.pone.0028755.

Huvenne, V.A.I., Bett, B.J., Masson, D.G., Le Bas, T.P., Wheeler, A.J., 2016. Effectiveness of a deep-sea cold-water coral Marine Protected Area, following eight years of fisheries closure. Biological Conservation 200, 60-69, 10.1016/j.biocon.2016.05.030.

Huvenne, V.A.I., Beyer, A., de Haas, H., Dekindt, K., Henriet, J.-P., Kozachenko, M., OluLe Roy, K., Wheeler, A.J., participants, T.P.c., participants, C.c., 2005. The seabed appearance of different coral bank provinces in the Porcupine Seabight, NE Atlantic: results from sidescan sonar and ROV seabed mapping. In: Freiwald, A., Roberts, J.M. (Eds.), Coldwater Corals and Ecosystems. Springer-Verlag, Berlin Heidelberg, pp. 535-569, http://dx.doi.org/10.1007/3-540-27673-4_27.

Huvenne, V.A.I., Blondel, P., Henriet, J.-P., 2002. Textural analyses of sidescan sonar imagery from two mound provinces in the Porcupine Seabight. Marine Geology 189 (3-4), 323-341, Pii Doi 10.1016/S0025-3227(02)00420-6.

Huvenne, V.A.I., Van Rooij, D., De Mol, B., Thierens, M., O’Donnell, R., Foubert, A.T.G., 2009. Sediment dynamics and palaeo-environmental context at key stages in the Challenger 
cold-water coral mound formation: Clues from sediment deposits at the mound base. Deep Sea Research Part I 56 (12), 2263-2280, 10.1016/j.dsr.2009.08.003.

IODP 307 Expedition scientists, 2005. Modern carbonate mounds: Porcupine drilling. IODP Prel. Rept., 307. p. 58, doi:10.2204/iodp.pr.307.2005

Janßen, A., Wizemann, A., Klicpera, A., Satari, D.Y., Westphal, H., Mann, T., 2017. Sediment Composition and Facies of Coral Reef Islands in the Spermonde Archipelago, Indonesia. Frontiers in Marine Science 4 (144), 10.3389/fmars.2017.00144.

Kano, A., Ferdelman, T.G., Williams, T., Henriet, J.-P., Ishikawa, T., Kawagoe, N., Takashima, C., Kakizaki, Y., Abe, K., Sakai, S., Browning, E.L., Li, X., Andres, M.S., Bjerager, M., Cragg, B.A., De Mol, B., Dorschel, B., Foubert, A.T.G., Frank, T.D., Fuwa, Y., Gaillot, P., Gharib, J.J., Gregg, J.M., Huvenne, V.A.I., Léonide, P., Mangelsdorf, K., Monteys, X., Novosel, I., O'Donnell, R., Rüggeberg, A., Samarkin, V.A., Sasaki, K., Spivack, A.J., Tanaka, A., Titschack, J., van Rooij, D., Wheeler, A.J., 2007. Age constraints on the origin and growth history of a deep-water coral mound in the northeast Atlantic drilled during Integrated Ocean Drilling Program Expedition 307. Geology 35 (11), 1051-1054, doi: 10.1130/G23917A.

Kocak, D.M., Caimi, F.M., 2005. The Current Art of Underwater Imaging \&\#8211; With a Glimpse of the Past and Vision of the Future. Marine Technology Society Journal 39 (3), 5$26,10.4031 / 002533205787442576$.

Kozachenko, M., 2005. Present and Past Environments of the Belgica Mounds (deep-water coral carbonate mounds) Eastern Porcupine Seabight, North East Atlantic (unpublished PhD Thesis), University College Cork, Cork,

Kwatra, V., Schödl, A., Essa, I., Turk, G., Bobick, A., 2003. Graphcut textures: image and video synthesis using graph cuts. ACM Transactions on Graphics (TOG). ACM, pp. 277 $286^{\wedge}$, http://dx.doi.org/10.1145/882262.882264.

Lamarche, G., Lurton, X., Verdier, A.-L., Augustin, J.-M., 2011. Quantitative characterisation of seafloor substrate and bedforms using advanced processing of multibeam backscatter-Application to Cook Strait, New Zealand. Continental Shelf Research 31 (2, Supplement), S93-S109, http://dx.doi.org/10.1016/j.csr.2010.06.001.

Lim, A., 2017. Spatio-temporal patterns and controls on cold-water coral reef development: the Moira Mounds, Porcupine Seabight, NE Atlantic, University College Cork, Cork Open Research Archive, http://hdl.handle.net/10468/4031.

Lirman, D., Gracias, N.R., Gintert, B.E., Gleason, A.C.R., Reid, R.P., Negahdaripour, S., Kramer, P., 2007. Development and application of a video-mosaic survey technology to document the status of coral reef communities. Environmental Monitoring and Assessment 125 (1), 59-73, 10.1007/s10661-006-9239-0.

Lowe, D.G., 1999. Object recognition from local scale-invariant features. Computer vision, 1999. The proceedings of the seventh IEEE international conference on Computer Vision. Ieee, pp. 1150-1157^, http://dx.doi.org/10.1109/ICCV.1999.790410.

Messing, C.G., Neumann, A.C., Lang, J.C., 1990. Biozonation of deep-water lithoherms and associated hardgrounds in the northeastern Straits of Florida. Palaios 5, 15-33, 
Mienis, F., de Stigter, H.C., de Haas, H., van Weering, T.C.E., 2009. Near-bed particle deposition and resuspension in a cold-water coral mound area at the Southwest Rockall Trough margin, NE Atlantic. Deep Sea Research Part I: Oceanographic Research Papers 56 (6), 1026-1038, http://dx.doi.org/10.1016/j.dsr.2009.01.006.

Mullins, H.T., Newton, C.R., Heath, K., Van Buren, H.M., 1981. Modern deep-water coral mounds north of Little Bahama Bank; criteria for recognition of deep-water coral bioherms in the rock record. Journal of sedimentary research 51 (3), 999-1013, 10.1306/212f7dfb-2b24$11 \mathrm{~d} 7-8648000102 \mathrm{c} 1865 \mathrm{~d}$.

Murphy, P., Wheeler, A.J., 2017. A GIS-based application of drainage basin analysis and geomorphometry in the submarine environment: The Gollum Canyon System, North-east Atlantic. In: Bartlett, D., Celliers, L. (Eds.), Geoinformatics for Marine and Coastal Management. CRC Press, Taylor \& Francis Group, Boca Raton, USA, http://dx.doi.org/10.1201/9781315181523-4.

Ord, J.K., Getis, A., 1995. Local Spatial Autocorrelation Statistics: Distributional Issues and an Application. Geographical Analysis 27 (4), 286-306, 10.1111/j.1538-

4632.1995.tb00912.x.

Orejas, C., Gori, A., Rad-Menendez, C., Last, K.S., Davies, A.J., Beveridge, C.M., Sadd, D., Kiriakoulakis, K., Witte, U., Roberts, J.M., 2016. The effect of flow speed and food size on the capture efficiency and feeding behaviour of the cold-water coral Lophelia pertusa. Journal of Experimental Marine Biology and Ecology 481, 34-40, 10.1016/j.jembe.2016.04.002.

Purser, A., 2015. A Time Series Study of Lophelia pertusa and Reef Megafauna Responses to Drill Cuttings Exposure on the Norwegian Margin. PLoS ONE 10 (7), e0134076, 10.1371/journal.pone.0134076.

Purser, A., Larsson, A.I., Thomsen, L., van Oevelen, D., 2010. The influence of flow velocity and food concentration on Lophelia pertusa (Scleractinia) zooplankton capture rates. Journal of Experimental Marine Biology and Ecology 395 (1-2), 55-62,

10.1016/j.jembe.2010.08.013.

Reolid, J., Betzler, C., Braga, J.C., Martín, J.M., Lindhorst, S., Reijmer, J.J.G., 2014. Reef slope geometries and facies distribution: controlling factors (Messinian, SE Spain). Facies 60 (3), 737-753, 10.1007/s10347-014-0406-4.

Roberts, J.M., Brown, C.J., Long, D., Bates, C.R., 2005. Acoustic mapping using a multibeam echosounder reveals cold-water coral reefs and surrounding habitats. Coral Reefs 24 (4), 654-669, 10.1007/s00338-005-0049-6.

Roberts, J.M., Long, D., Wilson, J.B., Mortensen, P.B., Gage, J.D., 2003. The cold-water coral Lophelia pertusa (Scleractinia) and enigmatic seabed mounds along the north-east Atlantic margin: are they related? Marine Pollution Bulletin 46 (1), 7-20, http://dx.doi.org/10.1016/S0025-326X(02)00259-X.

Roberts, J.M., Wheeler, A., Freiwald, A., Cairns, S., 2009. Cold-Water Corals: The Biology and Geology of Deep-Sea Coral Habitats. Cambridge University Press, http://books.google.ie/books?id=6WA3YIH27t0C 
Roberts, J.M., Wheeler, A.J., Freiwald, A., 2006. Reefs of the Deep: The Biology and Geology of Cold-Water Coral Ecosystems. Science 312 (5773), 543-547, http://dx.doi.org/10.1126/science.1119861.

Rüggeberg, A., Flögel, S., Dullo, W.-C., Hissmann, K., Freiwald, A., 2011. Water mass characteristics and sill dynamics in a subpolar cold-water coral reef setting at Stjernsund, northern Norway. Marine Geology 282 (1-2), 5-12, http://dx.doi.org/10.1016/j.margeo.2010.05.009.

Rzhanov, Y., Linnett, L.M., Forbes, R., 2000. Underwater video mosaicing for seabed mapping. Image Processing, 2000. Proceedings. 2000 International Conference on, pp. 224227 vol.221^, 10.1109/ICIP.2000.900935.

Savini, A., Vertino, A., Marchese, F., Beuck, L., Freiwald, A., 2014. Mapping cold-water coral habitats at different scales within the Northern Ionian Sea (Central Mediterranean): an assessment of coral coverage and associated vulnerability. PLoS ONE 9 (1), e87108, 10.1371/journal.pone.0087108.

Spezzaferri, S., Vertino, A., Addamo, A.M., Backers, J., Baratti, V., Constandache, M., Camozzi, O., El Kateb, A., Gennari, G., Leuzinger, L., McGrath, M., Mc Hugh, S.K., Naudts, L., Savini, A., Stalder, C., 2012. E-CWC Moira (2012/16) RV Belgica: Cold-water coral ecosystems from the Moira Mounds (NE Atlantic): affinities and differences with modern and Pleistocene Mediterranean counterparts. University Freibourg, Switzerland, Unpublished Cruise Report,

Squires, D.F., 1964. Fossil coral thickets in Wairarapa, New Zealand. Journal Paleontol. 38 (5), 904-915, http://www.jstor.org/stable/1301611

Thierens, M., Titschack, J., Dorschel, B., Huvenne, V.A.I., Wheeler, A.J., Stuut, J.-B.W., O'Donnell, R., 2010. The 2.6 Ma depositional sequence from the Challenger cold-water coral carbonate mound (IODP Exp. 307): sediment contributors and hydrodynamic palaeoenvironments. Marine Geology 271 (3-4), 260-277, doi:10.1016/j.margeo.2010.02.021.

Titschack, J., Thierens, M., Dorschel, B., Schulbert, C., Freiwald, A., Kano, A., Takashima, C., Kawagoe, N., Li, X., 2009. Carbonate budget of a cold-water coral mound (Challenger Mound, IODP Exp. 307). Marine Geology 259 (1-4), 36-46, 10.1016/j.margeo.2008.12.007.

Van Rooij, D., 2004. An integrated study of Quaternary sedimentary processes on the eastern slope of the Porcupine Seabight, SW of Ireland, Ghent University, http://dx.doi.org/1854/10815.

Vertino, A., Savini, A., Rosso, A., Di Geronimo, I., Mastrototaro, F., Sanfilippo, R., Gay, G., Etiope, G., 2010. Benthic habitat characterization and distribution from two representative sites of the deep-water SML Coral Province (Mediterranean). Deep-Sea Research Part IiTopical Studies in Oceanography 57 (5-6), 380-396, 10.1016/j.dsr2.2009.08.023.

Vertino, A., Spezzaferri, S., Ruggeberg, A., Stalder, C., Wheeler, A.J., Party, t.E.C.-M.c.S., 2015. An Overview on Cold-Water Coral Ecosystems and Facies. In: Spezzaferri, S.,

Ruggeberg, A., Stalder, C. (Eds.), Atlas of benthic foraminifera from cold-water coral reefs. Cushman Foundation for Foraminiferal Research, pp. 12-19, 
Wheeler, A.J., Beyer, A., Freiwald, A., de Haas, H., Huvenne, V.A.I., Kozachenko, M., OluLe Roy, K., Opderbecke, J., 2007. Morphology and environment of cold-water coral carbonate mounds on the NW European margin. International Journal of Earth Sciences 96 (1), 37-56, http://dx.doi.org/10.1007/s00531-006-0130-6.

Wheeler, A.J., Capocci, R., Crippa, L., Connolly, N., Hogan, R., Lim, A., McCarthy, E., McGonigle, C., O' Donnell, E., O' Sullivan, K., Power, K., Ryan, G., Vertino, A., Holland 1 ROV Technical Team, Officers and Crew of the RV Celtic Explorer, 2015. Cruise Report: Quantifying Environmental Controls on Cold-Water coral Reef Growth (QuERCi). University College Cork, Ireland,

Wheeler, A.J., Kozachenko, M., Beyer, A., Foubert, A.T.G., Huvenne, V.A.I., Klages, M., Masson, D.G., Olu-Le Roy, K., Thiede, J., 2005. Sedimentary processes and carbonate mounds in the Belgica Mound province, Porcupine Seabight, NE Atlantic. In: Freiwald, A., Roberts, J.M. (Eds.), Cold-water Corals and Ecosystems. Springer-Verlag, Berlin Heidelberg, pp. 533-564, http://dx.doi.org/10.1007/3-540-27673-4_28.

Wheeler, A.J., Kozachenko, M., Henry, L.A., Foubert, A., de Haas, H., Huvenne, V.A.I., Masson, D.G., Olu, K., 2011. The Moira Mounds, small cold-water coral banks in the Porcupine Seabight, NE Atlantic: Part A - an early stage growth phase for future coral carbonate mounds? Marine Geology 282 (1-2), 53-64, 10.1016/j.margeo.2010.08.006.

Wheeler, A.J., Kozachenko, M., Masson, D.G., Huvenne, V.A.I., 2008. Influence of benthic sediment transport on cold-water coral bank morphology and growth: the example of the Darwin Mounds, north-east Atlantic. Sedimentology 55 (6), 1875-1887, 10.1111/j.13653091.2008.00970.x.

Wheeler, A.J., shipboard party, 2011. Vents \& Reefs deep-sea ecosystem study of the $45^{\circ}$ North MAR hydrothermal vent field and the cold-water coral Moira Mounds, Porcupine Seabight. Cruise report, p. 160,

White, M., Dorschel, B., 2010. The importance of the permanent thermocline to the cold water coral carbonate mound distribution in the NE Atlantic. Earth and Planetary Science Letters 296, 395-402,

Wienberg, C., Beuck, L., Heidkamp, S., Hebbeln, D., Freiwald, A., Pfannkuche, O., Monteys, F.X., 2008. Franken Mound: facies and biocoenoses on a newly-discovered "carbonate mound" on the western Rockall Bank, NE Atlantic. Facies 54 (1), 1-24, 10.1007/s10347-0070118-0.

Wienberg, C., Hebbeln, D., Fink, H.G., Mienis, F., Dorschel, B., Vertino, A., López Correa, M., Freiwald, A., 2009. Scleractinian cold-water corals in the Gulf of Cádiz-first clues about their spatial and temporal distribution. Deep Sea Research Part I 56 (10), 1873-1893, doi:10.1016/j.dsr.2009.05.016.

Wienberg, C., Wintersteller, P., Beuck, L., Hebbeln, D., 2013. Coral Patch seamount (NE Atlantic) - a sedimentological and megafaunal reconnaissance based on video and hydroacoustic surveys. Biogeosciences 10, 3421-3443, 10.5194/bg-10-3421-2013. 
Wilson, J.B., 1979. "Patch" development of the deep-water coral Lophelia pertusa (L.) on the Rockall bank. Journal of the Marine Biological Association of the United Kingdom 59 (1), 165-177, http://dx.doi.org/10.1017/S0025315400046257.

Woodroffe, C.D., Biribo, N., 2011. Atolls. In: Hopley, D. (Ed.), Encyclopedia of Modern Coral Reefs: Structure, Form and Process. Springer Netherlands, Dordrecht, pp. 51-71, 10.1007/978-90-481-2639-2_4.

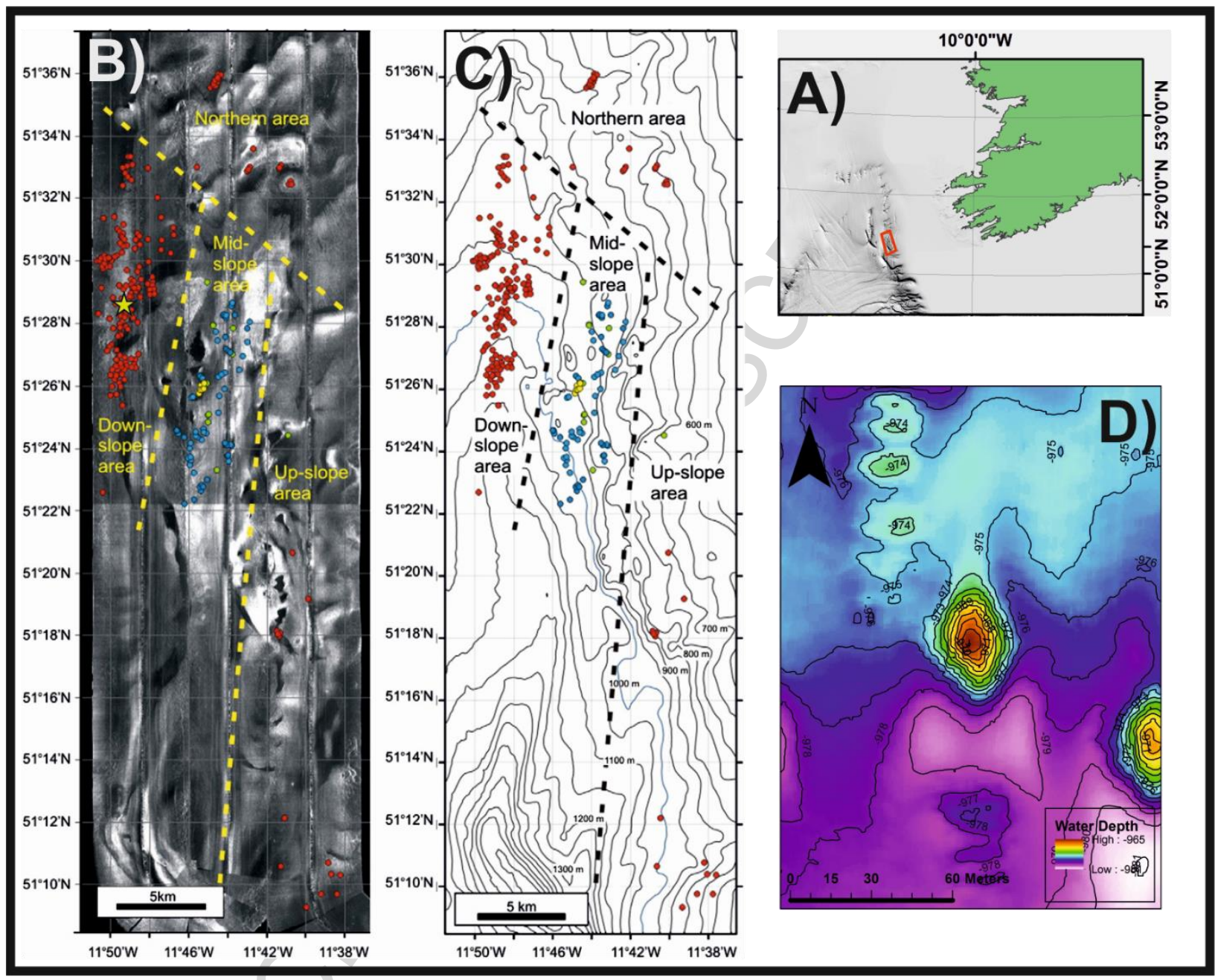

Figure 1 A) Map showing the Belgica Mound Province (BMP) Special Area of Conservation

(SAC) (red box) within the Porcupine Seabight relative to Ireland; B) the subdivision of Moira

Mounds with the position of the Piddington Mound (yellow star) with side scan sonar data in the background (white tones are high backscatter, darker tones are low backscatter), Red

dots= Moira Mounds identified on $30 \mathrm{kHz}$ side-scan sonar data; blue dots=Moira Mounds identified on $100 \mathrm{kHz}$ side-scan sonar data, green dots= Moira Mounds identified on $410 \mathrm{kHz}$ side-scan sonar data; yellow dots= Moira Mounds groundtruthed by ROV and identified on 
100 and $410 \mathrm{kHz}$ side-scan sonar after Wheeler et al. (2011); C) the subdivision of Moira Mounds after Wheeler et al. (2011); D) bathymetry of the Piddington Mound area.

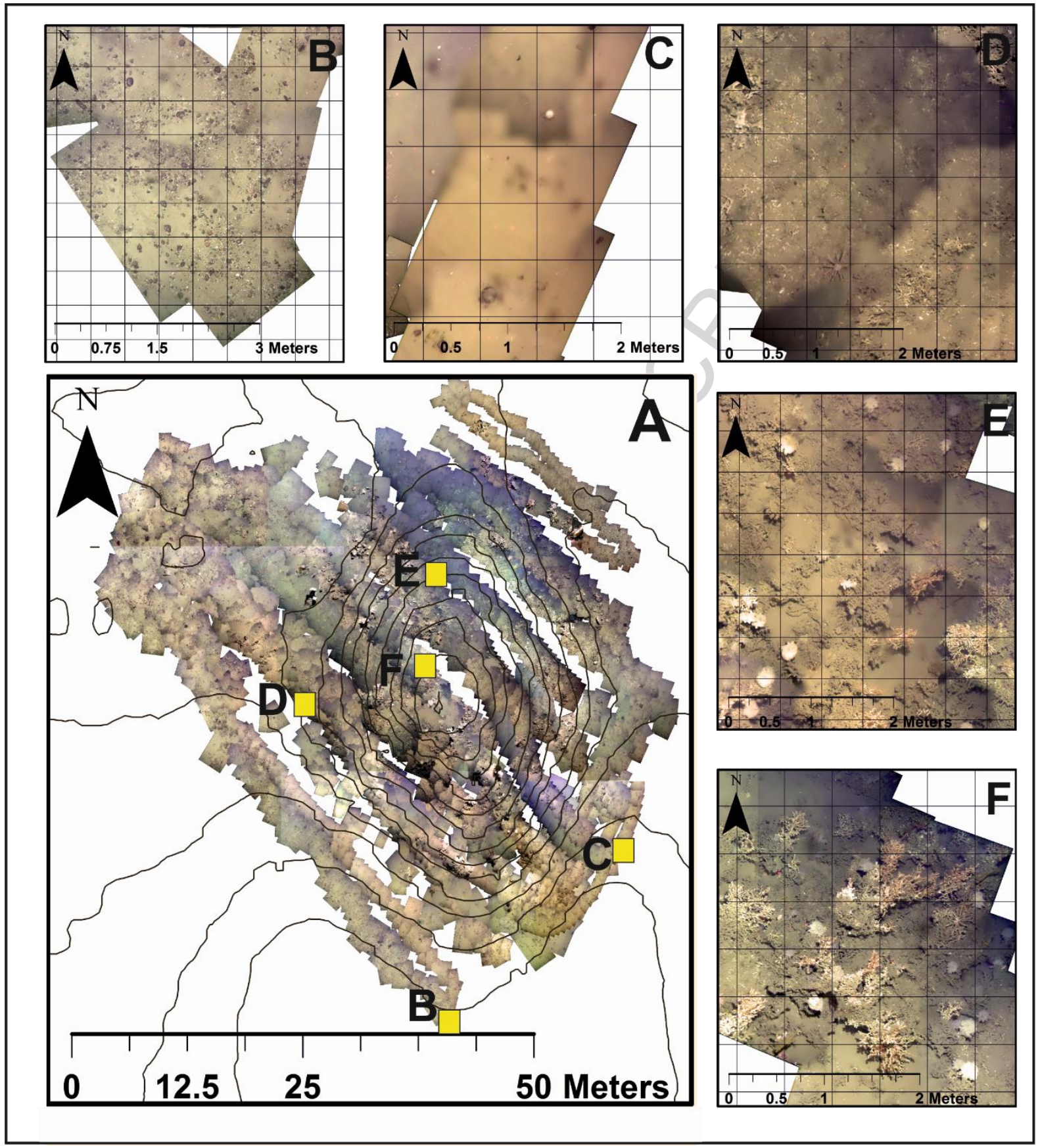

Figure 2 A) Map of georeferenced video mosaic with relative position of close-up images (yellow boxes) with $1 \mathrm{~m}$ contours superimposed; B) example close-up image of area dominated by "hemipelagic sediment and dropstone" cells with ArcGIS fishnet overlaid; C) example close-up image of area dominated by "hemipelagic sediment" cells with ArcGIS 
fishnet overlaid; D) example close-up image of area dominated by "coral rubble" cells with ArcGIS fishnet overlaid; E) example close-up image of area dominated by "dead coral framework" cell with ArcGIS fishnet overlaid; F) example close-up image of area dominated by "live coral framework" cells with ArcGIS fishnet overlaid. 


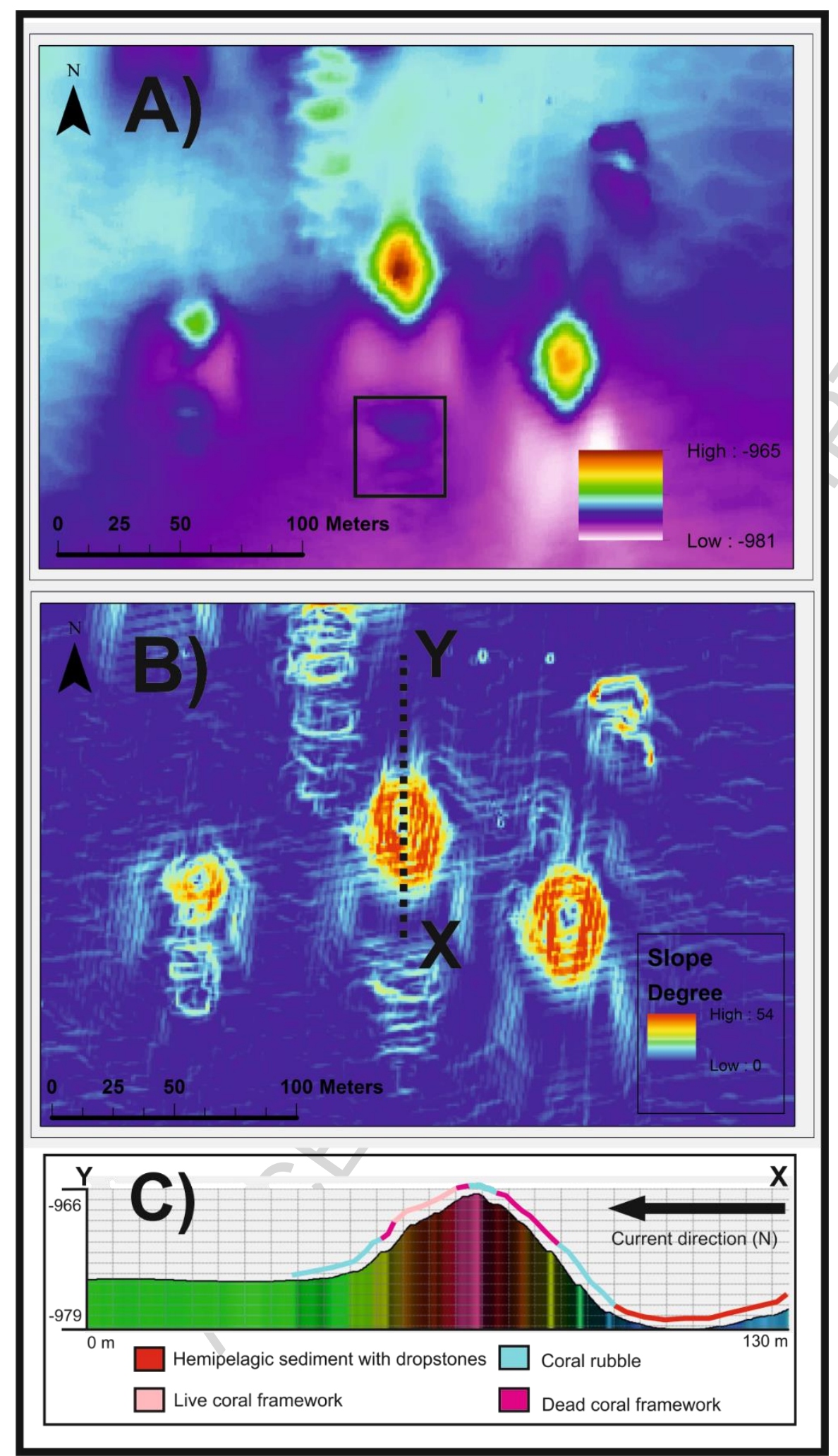

Figure 3 A) Bathymetry of the Piddington Mound (centre) area with coral ridge feature position identified (black box); B) ArcGIS-generated slope of the Piddington Mound area. Relatively 
flat areas in blue, relatively steep areas in red and line X-Y (Fig. 3C) indicated; C) Cross profile of Piddington Mound with facies type plotted across the surface.

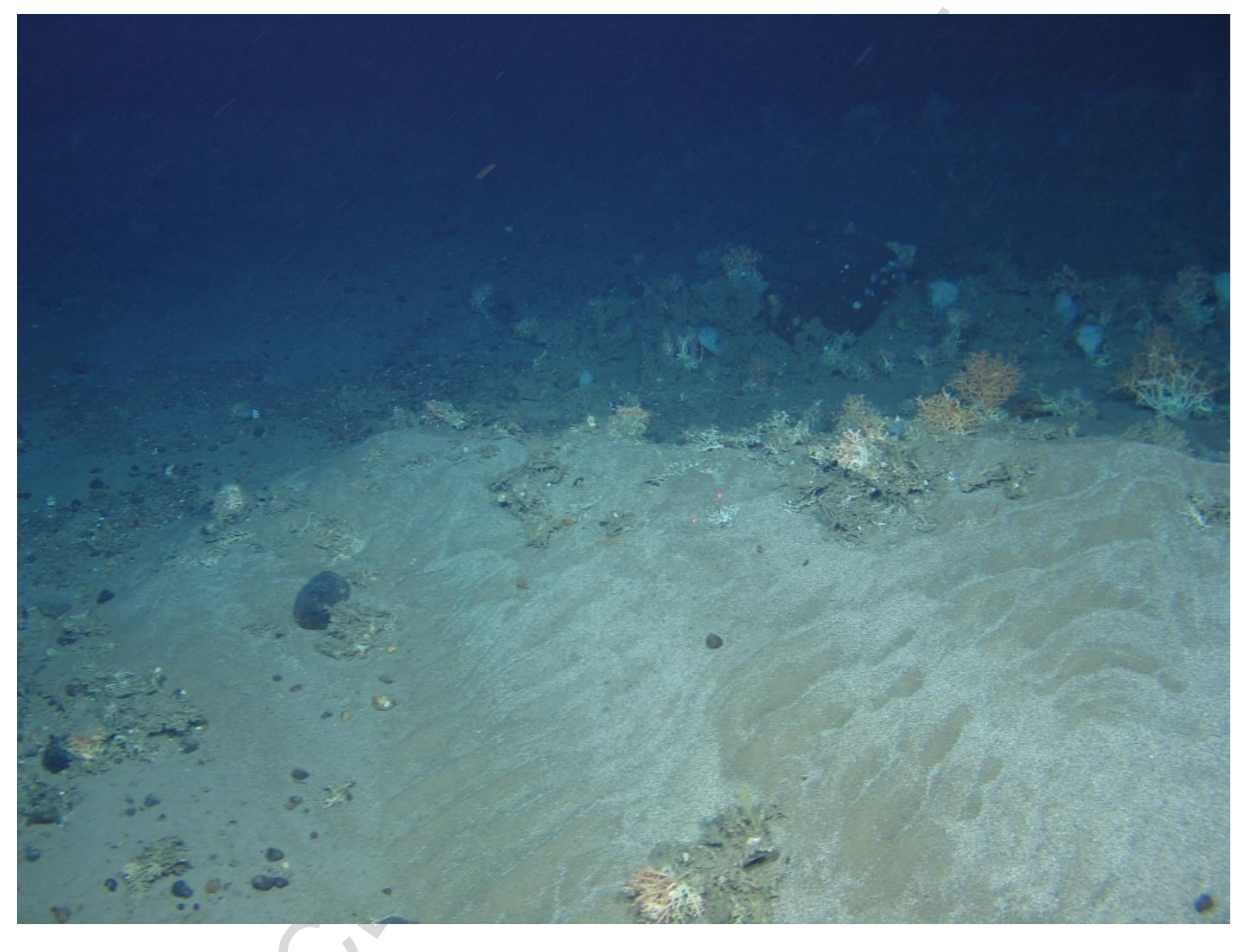

Figure 4 Image of ridge-form feature, covered with corals to the south of Piddington Mound. View to the north. Laser scalers $=11 \mathrm{~cm}$. Ripple marks on the camera-facing side of the ridge indicate a northerly-directed current. 


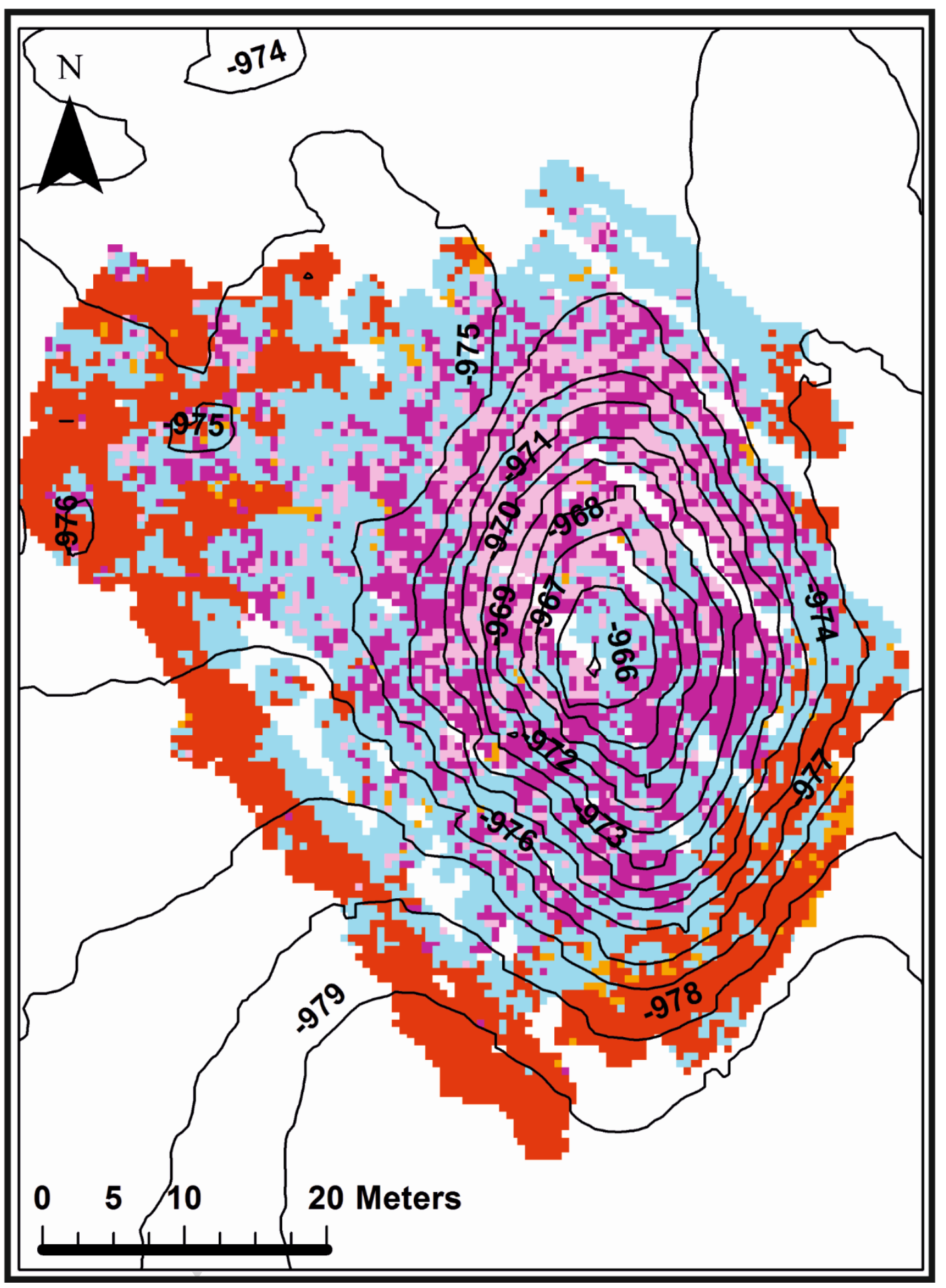

Figure 5 Classified fishnet $*$.shp file with contours superimposed showing the distribution of facies types across the Piddington Mound mosaic (red = hemipelagic sediment with dropstones, orange $=$ hemipelagic sediment, blue $=$ coral rubble, purple $=$ dead coral framework and pink $=$ live coral framework). 


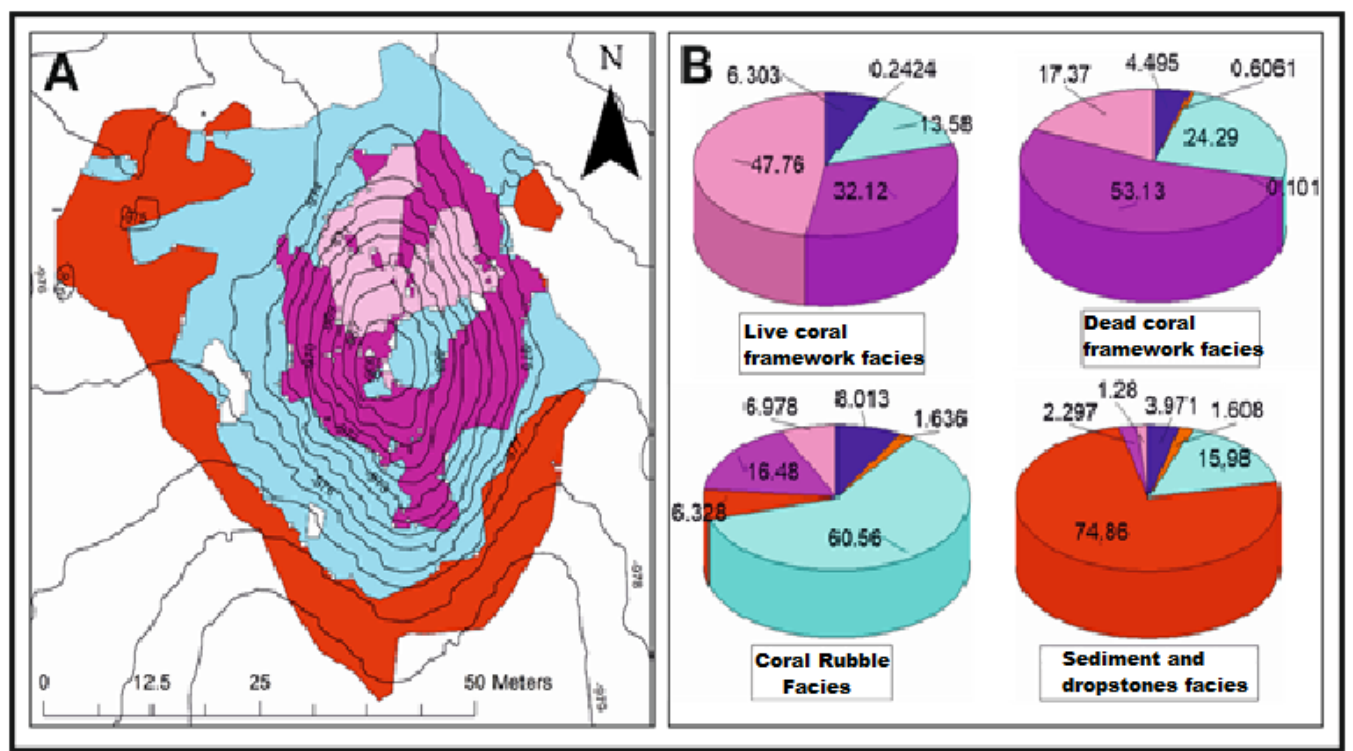

Figure 6 A) Map showing the focal statistics layer which shows the 4 identified facies occurring in 5 areas. Each facies represents where a cell-type is most dominant within a $2.5 \mathrm{~m}$ radius neighbourhood (red = "Hemipelagic sediment with dropstones" facies, blue = "Coral rubble" facies, dark pink = "Dead coral framework" facies, light pink = "Live coral framework" facies); B) Pie charts showing the relative proportion and percentages of cells that define each facies.

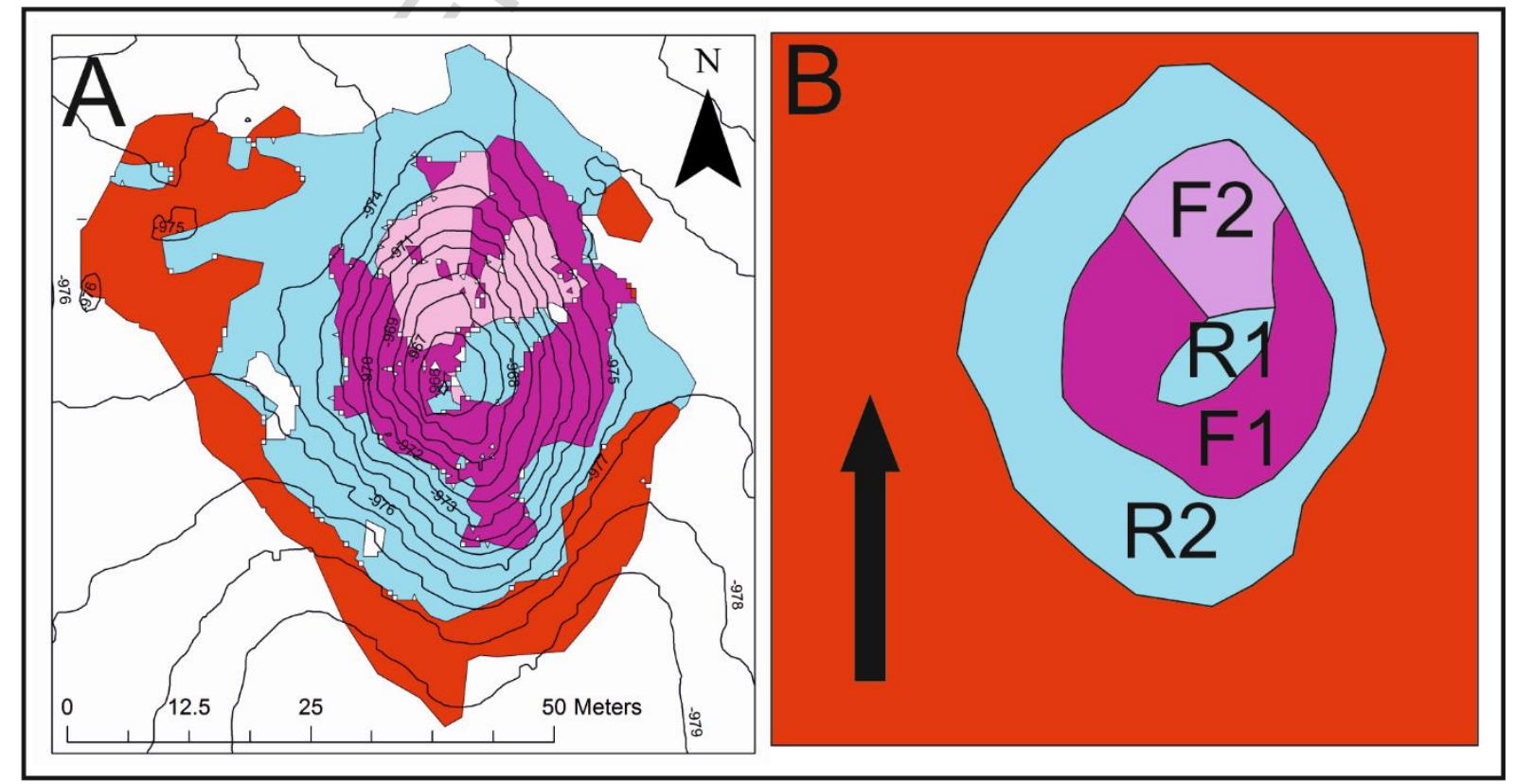


Figure 7 A) map showing the distribution of facies across Piddington Mound with $1 \mathrm{~m}$ contours overlaid $($ red $=$ hemipelagic sediment and dropstone facies, blue $=$ coral rubble facies, purple $=$ dead coral framework facies, pink = live coral framework facies) B) Simplified drawing of Piddington Mound with differentiation between live and dead coral frameworks (red = hemipelagic sediment and dropstone facies, blue $=$ coral rubble facies, purple $=$ combined coral framework facies, $\mathrm{R} 1 \& \mathrm{R} 2=$ coral rubble facies 2, F1 = dead coral framework facies, F2 = live coral framework facies, arrow = current direction). 